Original Research Paper

\title{
Evaluation of Effluent from the University of Nigeria, Nsukka Wastewater Treatment Plant for Irrigation Purposes
}

\author{
${ }^{1}$ Emmanuel Amagu Echiegu, ${ }^{2}$ Ogochukwu Ruth Eya, \\ ${ }^{1}$ Samson Nnaemeka Ugwu and ${ }^{1}$ Boniface Ugwuishiwu \\ ${ }^{I}$ Department of Agricultural and Bioresources Engineering, University of Nigeria, Nsukka, Nigeria \\ ${ }^{2}$ Department of Agricultural and Bioresource Engineering, \\ Enugu State University of Science and Technology, Enugu, Nigeria
}

Article history

Received: 21-06-2015

Revised: 14-04-2016

Accepted: 20-04-2016

Corresponding Author:

Echiegu, Emmanuel Amagu

Dept of Agric and Bioresources

Engineeing, University of

Nigeria, Nsukka, Nigeria

Email: emmanuel.echiegu@unn.edu.ng

\begin{abstract}
This study was carried out to determine the suitability of effluents from the University of Nigeria, Nsukka (UNN) sewage treatment facility for irrigation purposes. The result shows that, from the point of view of $\mathrm{EC}_{\mathrm{w}}$, SAR, solids, organic matter content, ion toxicity and nutrients (except Phosphate), the UNN wastewater treatment plant effluent can be safely used for irrigation, especially under short term. Although the fecal coliform load is within the value allowed for irrigation water, it is recommended that irrigation must cease at least two weeks before the crop is harvested to avoid any form of contamination. The effluent quality of the sewage plant also substantially met the effluent quality standards of Nigeria and other countries.
\end{abstract}

Keywords: Effluent, University of Nigeria, Irrigation Wastewater Quality

\section{Introduction}

Expansion of our urban communities and greater improvement in our domestic water supply and sewerage has given rise to greater quantities of municipal wastewater. With the current emphasis on environmental health and water pollution issues, there is an increasing awareness of the need to dispose of these wastewaters safely and beneficially and with water becoming an increasingly scarce resource in many arid and semi arid countries, the use of wastewater in agriculture is an important consideration especially in these regions (Shuval et al., 1986; Biswas and Arar, 1988; Ayers and Westcot, 1994; Shalhevet, 1994; Qadir et al., 2007). In fact, the increasing scarcity of good quality water resources and rising fertilizer prices are the driving forces behind the accelerating upward trend in the use of wastewater for agriculture and aquaculture. Although the quantity of wastewater available in most countries will account for only a small fraction of the total irrigation water requirements, wastewater use will result in the conservation of higher quality water and its use for purposes other than irrigation. The use of treated wastewater for irrigation and other agricultural purposes has other advantages. It provides a renewable and valuable source for release from limited fresh water supplies for municipal and agricultural purposes and so decreases the pressure on water resources. It eliminates discharge of effluent into surface water and the associated water pollution problems. The plant nutrients load can be an important factor in saving on the cost of fertilizer. The organic matter content also improves physical properties of the soil. It prevents or postpones the need for the high cost advanced treatment facilities which will provide adequate treatment to permit discharge to the wastewater receiving bodies.

The University of Nigeria, Nsukka (UNN), sewage treatment facility provides a good source of marginal water which is employed by some members of the university community for the production of vegetables. Although this practice has been on for over 30 years, not much is known of the suitability of this marginal water for the irrigation purpose. The aim of this study was to determine the quality of this wastewater with a view to finding out its suitability or not for irrigation purposes as is currently being practiced by some members of the university community.

\section{Materials and Method}

\section{The Study Site}

The experimental site is the University of Nigeria, Nsukka (UNN) Wastewater Treatment Plant (WWTP). 
UNN is the first autonomous university in Nigeria and is located at Nsukka in Enugu State, South-East, Nigeria. The treatment plant is located at the northwestern end of the campus, some $500 \mathrm{~mm}$ from the Junior Staff Quarters. It comprises a screen, a primary settling (Imhoff) tank, sludge drying beds and two oxidation ponds in series (Fig. 1). Domestic sewage from the various staff houses are collected through pipes and through screens into the primary treatment unit (Imhoff tank). From the primary treatment unit the sewage enters the first oxidation pond where intermediate effluents are produced. These effluents then undergo further treatment as they pass through the second oxidation pond which yields the final effluents which is then used for irrigating crop on the nearby land. Wastewater irrigation around the treatment works has been in practice since 1976. The total area under cultivation is estimated to be 4.6 hectares. The system of irrigation adopted is the corrugated type of furrow irrigation. Wastewater is conveyed from the treatment works to the corrugation by gravity through temporary diversions and by direct lifting of wastewater from the source with buckets or other containers. The main crops grown during the dry season are the green vegetable (amaranthus Spp) which is popularly known as 'green', garden egg and fluted pumpkin (Telfaria Occidentalis).

\section{Collection of Effluent Samples}

The wastewater sample for this study was collected manually from the final effluent discharge section of the treatment plant using sterilized plastic containers. Grab samples were collected on weekly bases for a period of six months (February-July, 2013) between the hours of $11.00 \mathrm{am}$ and 12.00 noon each day. A total of 24 samples were collected. The containers were labeled, transported immediately in a container of ice and stored in a refrigerator at $4{ }^{\circ} \mathrm{C}$ until they are analyzed and after each analysis to avoid biological actions.

\section{Method of Analysis}

The samples were analyzed for solids, $\mathrm{pH}$, coliform, COD, BOD, sodium, calcium, magnesium, chloride, boron, copper, nitrate, potassium and phosphate as well as coliform using the laboratory facilities of the Civil Engineering Department of the UNN.

\section{Solids}

Solids determination was carried out following the procedure outlined in Standard Method (APHA and AWWA, 2012). The Total Solid (TS) was determined gravimetrically by evaporating a known volume of the effluent sample to dryness at $104^{\circ} \mathrm{C}$ in a ventilated oven until a constant weight was achieved.

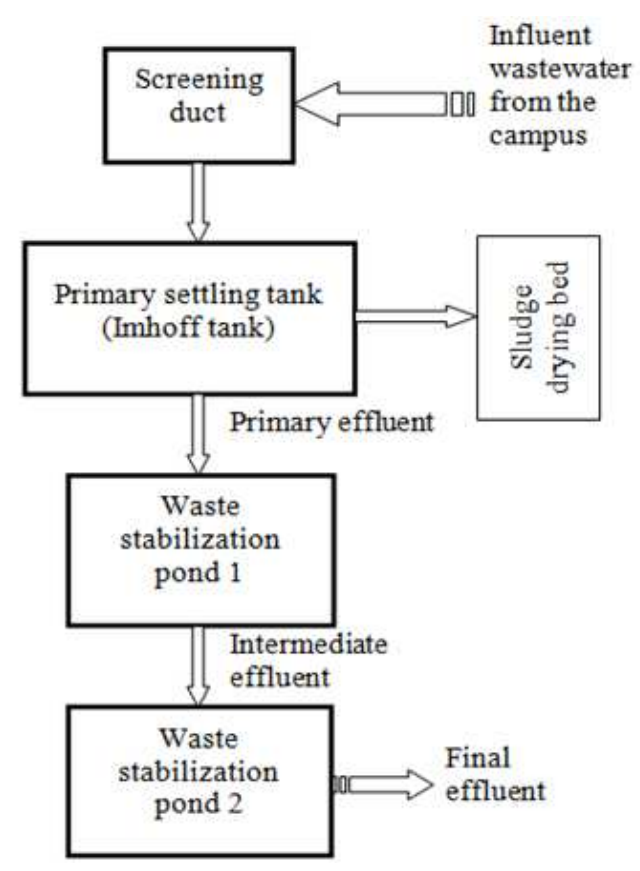

Fig. 1. Schematics of the UNN wastewater treatment plant

Total Suspended Solids (TSS) were determined gravimetrically by filtering a known volume of the effluent sample using a vacuum filtration apparatus and Whatman No. 40 filter paper, drying the residue and the filter paper at $104^{\circ} \mathrm{C}$ and determining the mass of residue left on the filter paper. The Total Dissolved Solid (TDS) was determined as the difference between TS and TSS. $p H$

This was determined using a portable $\mathrm{pH}$ meter (HACH Senson 3).

\section{Chemical Oxygen Demand (COD)}

The COD of the samples were determined by refluxing a known volume of each sample with a known amount of potassium dichromate $\left(\mathrm{K}_{2} \mathrm{Cr}_{2} \mathrm{O}_{7}\right)$ in the presence of sulphuric acid $\left(\mathrm{H}_{2} \mathrm{SO}_{4}\right)$, silver sulphate $\left(\mathrm{AgSO}_{4}\right)$ and mercuric sulphate $\left(\mathrm{HgSO}_{4}\right)$. The amount of dichromate left after the reflux was determined by titration against ferrous ammonium sulphate $\left[\mathrm{Fe}\left(\mathrm{NH}_{4}\right)_{2}\left(\mathrm{SO}_{4}\right)_{2} \cdot 6 \mathrm{H}_{2} \mathrm{O}\right]$, using ferrroin as indicator as described by Standard Methods (APHA and AWWA, 2012). Similar volume of blank sample consisting of distilled water was equally refluxed and titrated. The COD was computed from:

$C O D=\frac{(A-B) * N * 8000}{V_{s}} \frac{m g}{L}$

where, $A=\mathrm{mL}$ of $\left[\mathrm{Fe}\left(\mathrm{NH}_{4}\right)_{2}\left(\mathrm{SO}_{4}\right)_{2} \cdot 6 \mathrm{H}_{2} \mathrm{O}\right]$ in a blank sample, $B=\mathrm{mL}$ of $\left[\mathrm{Fe}\left(\mathrm{NH}_{4}\right)_{2}\left(\mathrm{SO}_{4}\right)_{2} \cdot 6 \mathrm{H}_{2} \mathrm{O}\right]$ in the 
effluent sample, $N=$ normality of the titrant and $V_{s}=$ the $\mathrm{mL}$ of sample.

\section{Biochemical Oxygen Demand (BOD)}

This was determined by preparing and placing different volumes of the wastewater samples in BOD bottles and diluting each sample to $300 \mathrm{~mL}$ with organic-free and oxygen-saturated (distilled) water. The initial Dissolved Oxygen (DO) concentrations were determined using DO meters. The bottles were then tightly cocked and placed in an incubator maintained at $20^{\circ} \mathrm{C}$ for 5 days after which the final dissolved oxygen content of the samples were determined. The five day $\mathrm{BOD}\left(\mathrm{BOD}_{5}\right)$ for the samples in $\mathrm{mg} / \mathrm{L}$ were determined from:

$B O D_{5}=\frac{D O_{i}-D O_{f}}{P}$

where, $D O_{i}, D O_{f}$ and $P$ are the initial and final DO concentrations and dilution fraction, respectively.

\section{Coliform Count}

Multiple Tube Fermentation technique was employed to statistically estimate the number of coliform bacteria in a given volume of the samples following the method outlined in APHA and AWWA (2012). A three-fold dilution series was prepared for each sample using Lauryl Tryptose Broth (LTB) tubes for the presumptive test and Brilliant Green Bile broth (BGB) for the confirmatory test. After incubation at $37^{\circ} \mathrm{C}$ for $12-48 \pm 3$ $\mathrm{h}$, the pattern of positives and negatives were noted and a standardized MPN table consulted to determine the most probable number of organisms (causing the positive results) per $100 \mathrm{~mL}$ of each of the effluent samples.

\section{Other Parameters}

These were carried out in accordance with Standard Method for the Examination of Wastewater by (APHA and AWWA, 2012). Also qualitative inorganic analysis as described by Vogel, (2000) was used in some of the analysis.

\section{Results and Discussion}

The results of the laboratory analysis of the wastewater samples are shown in Fig 2 to 5.

\section{Salinity}

Water salinity is primarily measured by electrical conductivity $\left(\mathrm{EC}_{\mathrm{w}}\right)$. The mean $\mathrm{EC}_{\mathrm{w}}$ value for the effluent samples was $0.052 \mathrm{dS} \mathrm{m}^{-1}$ at $25^{\circ} \mathrm{C}$. This compares well with salinity value of 0.06 obtained for irrigation waters from Shari River in Chad Republic (Grove, 1972) and for great Usulu River at Sipofaneni in Swaziland. It also compares well with the values of 0.05 obtained for irrigation water from Niger River in Katon Karfi, Nigeria (Grove, 1972), 0.04 for Amazon River irrigation water in Brazil (Oltman, 1968) and 0.05 for Bio Bi River in Chile (Durum et al., 1960).

Water salinity is one of the most influential water quality parameter that affects crop productivity. The primary effect of high $\mathrm{EC}_{\mathrm{w}}$ irrigation water on crop productivity is the inability of the plant to compete with ions in the soil solution for water (Bauder et al., 2014). The more salt in the root zone, the harder the plant must work to take-up water (Camberato, 2001) as a result of osmotic effect. The higher the $\mathrm{EC}_{\mathrm{w}}$, the less water is available to plant even though the soil may appear wet a situation often referred to as physiological drought. Since plants can only transpire pure water, useable plant water decreases dramatically with increase in $\mathrm{EC}_{\mathrm{w}}$. When $\mathrm{EC}_{\mathrm{w}}$ is below $0.25 \mathrm{dS} \mathrm{m}^{-1}$, there are usually no detrimental effects for most plants (Hopkins et al., 2007; Ayers and Westcot, 1994; Bauder et al., 2014). Between 0.75 and $1.5 \mathrm{dS} \mathrm{m}^{-1}$, there may be some limitation. At $\mathrm{EC}_{\mathrm{w}}$ range of 1.51-3.0 dS m${ }^{-1}$ leaching may be required especially at the higher range to mitigate the effect of salinity. Above $3.0 \mathrm{dS} \mathrm{m} \mathrm{m}^{-1}$ good drainage is required and sensitive plant may have difficulty germinating as high salinity makes it more difficult for the seed to imbibe water needed for germination. In general, water with $\mathrm{EC}_{\mathrm{w}}$ values below $0.75 \mathrm{dS} \mathrm{m} \mathrm{m}^{-1}$ are satisfactory for irrigation purposes in so far as salt content is concerned although salt-sensitive crops may be adversely affected by use of irrigation water having conductivity values in the range of $0.25-0.75 \mathrm{dS} \mathrm{m}^{-1}$.

With the mean $\mathrm{EC}_{\mathrm{w}}$ value of $0.052 \mathrm{dS} \mathrm{m} \mathrm{m}^{-1}$ at $25^{\circ} \mathrm{C}$ for the effluent samples and from the point of view of salinity, the UNN WWTP effluent may be used for irrigation purposes without any detrimental effect.

\section{Solids and Organic Matter Content}

\section{Total Dissolved Solids}

TDS is another way of quantifying the amount of dissolved salt in water and hence a measure of the salinity. While $\mathrm{EC}_{\mathrm{w}}$ measures the dissolved ion indirectly by determining the electrical conductivity of the solution, TDS is a direct measure of the dissolved ions. The average TDS for the effluent samples was $33 \pm 2.6 \mathrm{mg} \mathrm{L}^{-1}$ at $95 \%$ confidence level (Fig. 2). A TDS value of less than 160 $\mathrm{mg} \mathrm{L}$ is usually considered to have very low hazard with no detrimental effects on crops and no soil build-up expected (Hopkins et al., 2007). Holmes (1996) indicated that a TDS level of less than or equal $40 \mathrm{mg} \mathrm{L}^{-1}$ are acceptable in irrigation water while Ayers and Westcot (1994) indicates that when the TDS is less than $450 \mathrm{mg}$ $\mathrm{L}^{-1}$ there is no restriction in the use of water for irrigation purposes. Therefore from the point of view of TDS, the effluent from the UNN waste treatment facility can be satisfactorily used for irrigation purposes. 


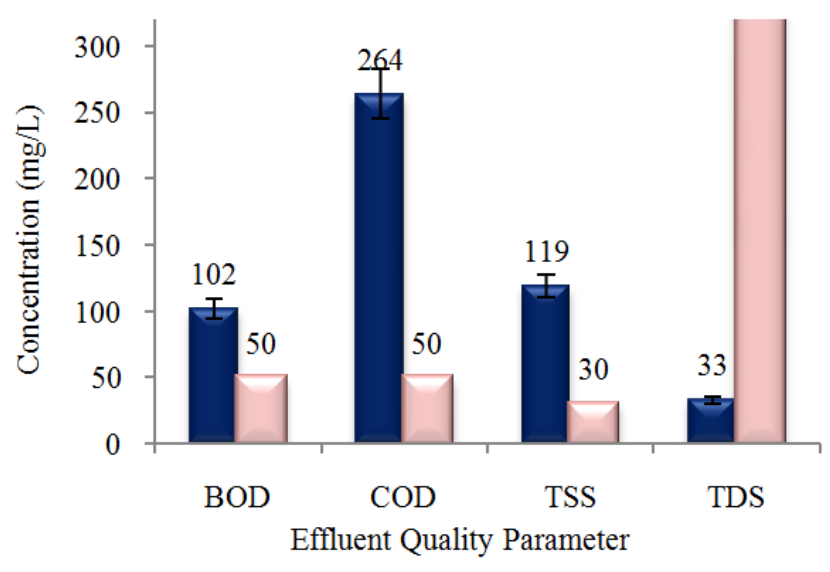

- Effluent Sample (mg/L) $₫$ Irrigation Water Quality Standard

Fig. 2. TDS, TSS, BOD and COD of samples compared with irrigation water quality standard

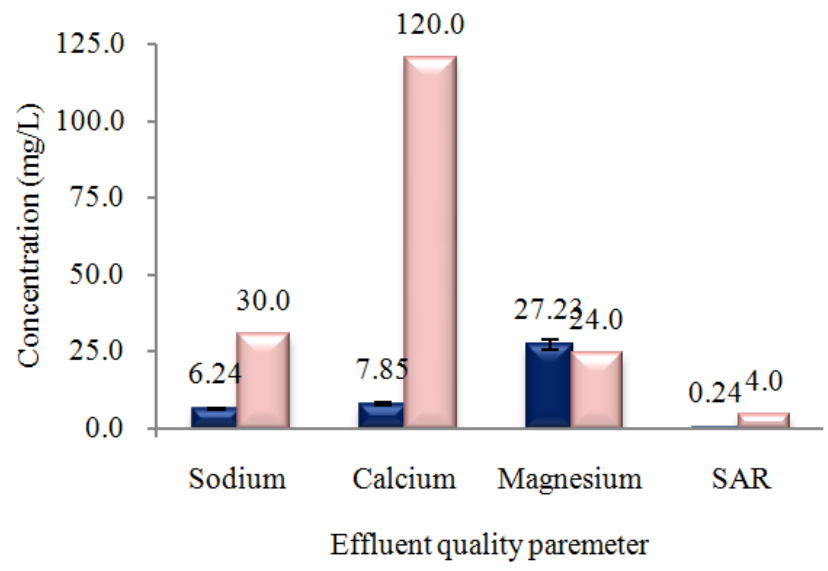

- Effluent Sample (mg/L) 『Irrigation Water Quality Standard

Fig. 3. Sodium, calcium and magnesium concentration and the SAR of effluent samples compared with Irrigation Water Quality Standard

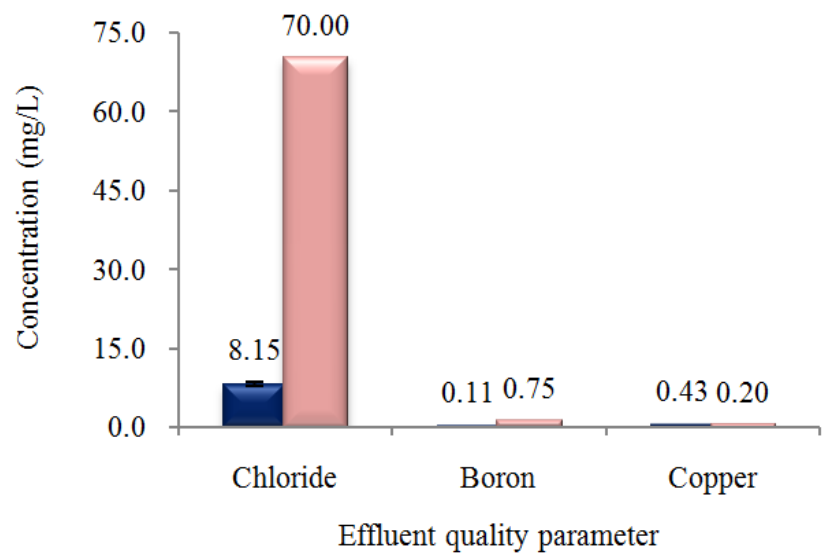

- Effluent Sample (mg/L) $₫$ Irrigation Water Quality Standard

Fig. 4. Toxic ions concentration in the effluent samples compared with Nigerian Effluent Quality Standard 


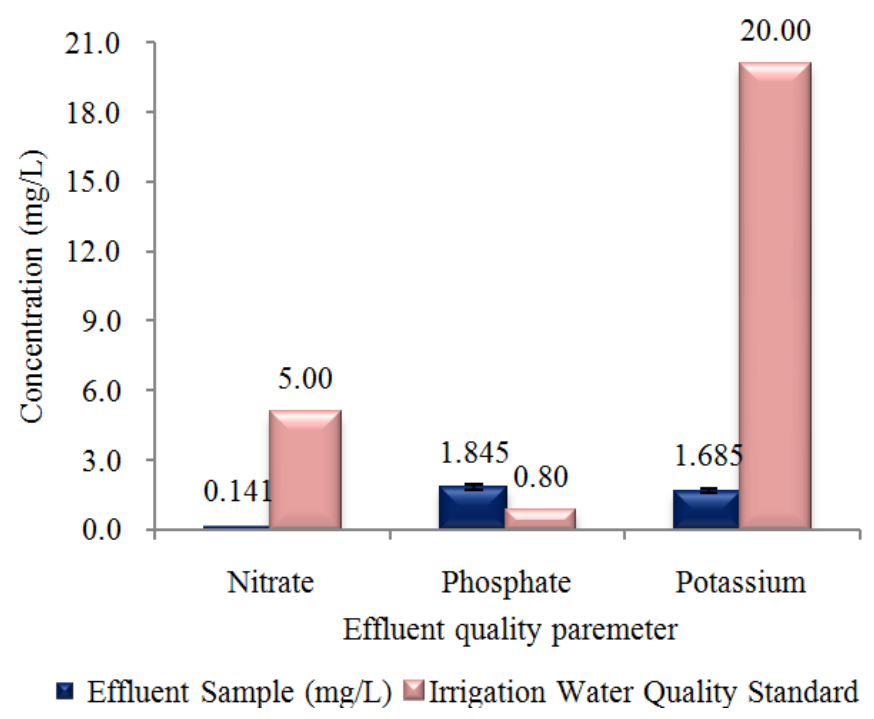

Fig. 5. Nutrient concentration in the effluent samples compared with Nigerian Effluent Quality Standard

\section{Total Suspended Solids}

The mean concentration of Total Suspended Solids (TSS) in the effluent samples was $119 \pm 3.6 \mathrm{mg} \mathrm{L}^{-1}$ at 95\% confidence level (Fig. 2). Holmes (1996) indicated that a TSS level of $0-50 \mathrm{mg} \mathrm{L}^{-1}$ is acceptable in irrigation water. Although the TSS value is higher than the recommended value, this may not pose serious problem since surface and not sprinkler irrigation is practiced at the site.

\section{$B O D$ and $C O D$}

The BOD and COD in the effluent samples were $102 \pm 3$ and $264 \pm 35 \mathrm{mg} \mathrm{L}^{-1}$, respectively at $95 \%$ confidence level (Fig. 2). Flood (1996) gave the desired BOD concentration in irrigation water as 100 $\mathrm{mg} \mathrm{L}^{-1}$. The values for these parameters obtained for the effluent samples are seen to be fairly within the acceptable limit except for the COD which is fairly relatively high.

\section{Sodium Hazard}

High sodium content in irrigation water contributes to salinity problem. Application of water with sodium imbalance further reduces crop yield under certain soil texture conditions (Bauder et al., 2014). Accumulation of sodium in soils causes swelling and dispersion of soil clays, surface crusting, pore plugging and increased imperviousness to water penetration (Fipps, 2003; Bauder et al., 2014). The degraded soil structure condition, apart from obstructing infiltration, also increases runoff. The decrease in downward movement of water into and through the soil deprives actively growing plant root from adequate water supply even though water may pool at the surface after irrigation. Sodium also interferes with magnesium and calcium ion availability. Conversely, the presence of $\mathrm{Ca}^{2+}$ and $\mathrm{Mg}^{2+}$ tends to counter the effect of sodium.

The most common method of assessing the potentials of infiltration problems due to sodium imbalance is Sodium Adsorption Ratio (SAR). This defines the sodium hazard problems in terms of the relative proportions of $\mathrm{Na}, \mathrm{Ca}$ and $\mathrm{Mg}$. It is calculated as:

$$
S A R=\frac{\left[\mathrm{Na}^{+}\right]}{\sqrt{\frac{\left[\mathrm{Ca}^{2+}\right]+\left[\mathrm{Mg}^{2+}\right]}{2}}}
$$

where, $\left[\mathrm{Na}^{+}\right],\left[\mathrm{Ca}^{2+}\right],\left[\mathrm{Mg}^{2+}\right]$ are the concentrations of $\mathrm{Na}, \mathrm{Ca}$ and $\mathrm{Mg}$, respectively in meq $\mathrm{L}^{-1}$. The higher the SAR, the greater the risk of causing damage to the soil structure.

The determined mean concentration of sodium in the effluent samples was $6.239 \pm 0.02\left(0.272 \mathrm{meq} \mathrm{L}^{-1}\right)$ at $95 \%$ confidence level $\mathrm{mg} / \mathrm{L}$ (Fig. 3). The SAR of the sewage plant effluent was therefore 0.237. Sodium concentrations of less than $3.0 \mathrm{mg} \mathrm{L}^{-1}$ is usually considered safe for sprinkler irrigation systems (Ayers and Westcot, 1994; FAO, 2006; LENNTECH, 2014a) while a concentration of $30 \mathrm{mg} \mathrm{L}^{-1}$ is considered safe for greenhouse irrigation (Flood, 1996). The calcium and magnesium concentration for the effluent was an average of $7.85 \mathrm{mg} \mathrm{L}^{-1}\left(0.393 \mathrm{meq} \mathrm{L}^{-1}\right)$ and $27.23 \mathrm{mg} \mathrm{L}^{-1}$ (2.241 meq $\mathrm{L}^{-1}$ ) respectively (Fig. 3). A calcium concentration of less than $120 \mathrm{mg} \mathrm{L}^{-1}$ and a magnesium concentration of less than $24 \mathrm{mg} \mathrm{L}^{-1}$ are considered safe for greenhouse irrigation water (Flood, 1996). 
An SAR of less than 3.0 is usually considered safe for irrigation and attracts no restriction on use (Ayers and Westcot, 1994; Hopkins et al., 2007; Bauder et al., 2014; LENNTECH, 2014a). When SAR is greater than 9.0, it can lead to severe damage and therefore unsuitable. With an SAR of 0.237 determined for the effluent samples, the UNN sewage treatment plant effluent can be said to be safe for irrigation purposes from the point of view of sodium toxicity. However, the SAR is usually not enough by itself to predict the impact of irrigation water on soils. Among other parameters, $\mathrm{EC}_{\mathrm{w}}$ affects SAR hazard potentials. Because both SAR and $\mathrm{EC}_{\mathrm{w}}$ both affect water infiltration, they are usually considered together in estimating water infiltration hazards. An SAR of between 0-3.0 and an $\mathrm{EC}_{\mathrm{w}}>7$ result in low risk of water infiltration problems (Ayers and Westcot, 1994; Hopkins et al., 2007; Bauder et al., 2014; LENNTECH, 2014a). If the $\mathrm{EC}_{\mathrm{w}}<2$ while the SAR remains within the range of 0 3.0, there may be severe infiltration problem. Therefore with the SAR of 0.237 and an $E_{\mathrm{w}}$ of 0.052 , the UNN sewage plant effluent may not be suitable for irrigation because of potential infiltration problem and its resultant effect on crop production.

\section{Specific Ion Toxicity}

\section{Chloride}

Excessive chloride in irrigation water can cause foliar burns. A chloride level of less than $70 \mathrm{mg} \mathrm{L}^{-1}$ is usually considered safe for most plants (Hopkins et al., 2007) although other studies indicate that chloride concentration below $140 \mathrm{mg} \mathrm{L}^{-1}$ may not be toxic to plant or cause foliar injury (Bauder et al., 2014; Ayers and Westcot, 1994; Flood, 1996). The chloride concentration in the effluent sample was $8.15 \pm 0.42 \mathrm{mg} \mathrm{L}^{-1}$ at $95 \%$ confidence level (Fig. 4) indicating that from the point of view of chloride concentration, crops can be safely irrigated with the UNN waste treatment plant effluent.

\section{Copper}

The mean concentration of copper in the effluent samples was $0.425 \pm 0.09 \mathrm{mg} \mathrm{L}^{-1}$ at $95 \%$ confidence level (Fig. 4). A Cu concentration of $5.0 \mathrm{mg} \mathrm{L}^{-1}$ may be tolerated by plant under short term. However, for long term use the phytotoxic threshold level is $0.2 \mathrm{mg} \mathrm{L}^{-1}$ (LENNTECH, 2014b; Fipps, 2003) with an optimum range of $0.08-0.15 \mathrm{mg} \mathrm{L}^{-1}$ (Flood, 1996). Ayers and Westcot (1994) indicates that $\mathrm{Cu}$ can be toxic to a number of plants at concentrations of $0.1-1.0 \mathrm{mg} \mathrm{L}^{-1}$ in nutrient solution. Holmes (1986) gave the acceptable level of copper concentration in irrigation water to be $0.0-0.2 \mathrm{mg} \mathrm{L}^{-1}$. With a $\mathrm{Cu}$ concentration of $0.425 \mathrm{mg}$ $\mathrm{L}^{-1}$, the UNN sewage plant effluent is seen to be unsuitable for long term irrigation purposes.

\section{Boron}

In low concentration, boron is an essential element for plants. However at high concentration in irrigation water, it can be toxic. The upper limit of boron concentration is $0.7 \mathrm{mg} \mathrm{L}^{-1}$ (Bauder et al., 2014; Ayers and Westcot, 1994) with an optimum range of $0.2-0.5 \mathrm{mg} \mathrm{L}^{-1}$. Most plants exhibit toxicity problem when boron concentration exceeds $2.0 \mathrm{mg} \mathrm{L}^{-1}$ while sensitive plants can show signs of boron toxicity at concentration of less than $0.5 \mathrm{mg} \mathrm{L}^{-1}$ (LENNTECH, 2014b; Hussien et al., 2010; Fipps, 2003). The boron concentration of the effluent sample was $0.11 \pm 0.005$ $\mathrm{mg} \mathrm{L}^{-1}$ at $95 \%$ confidence level (Fig. 4) indicating that plants irrigated with the effluent may not suffer from boron toxicity problem.

\section{$p H$ and Alkalinity}

The normal $\mathrm{pH}$ range for irrigation water is 6.5-8.4 (Ayers and Westcot, 1994). Abnormally low pH cause corrosion problems in irrigation equipment while high $\mathrm{pH}$ caused by high bicarbonate concentration can be a problem in drip and micro-irrigation as scale deposit resulting from precipitation of bicarbonates can lead to blockage of nozzles and emitters. The mean $\mathrm{pH}$ value for the samples was $7.9 \pm 0.6$ at $95 \%$ confidence level. This is well within the range for irrigation water. The bicarbonate concentration of $87 \mathrm{mg} \mathrm{L}^{-1}$ also indicates that from the point of view of bicarbonate concentration, the effluent is suitable even for sprinkler or drip irrigation.

\section{Nutrients}

\section{Nitrate}

The mean value of nitrate concentration in the effluent samples was $0.141 \pm 0.02 \mathrm{mg} \mathrm{L}^{-1}$ at $95 \%$ confidence level $\mathrm{mg} / \mathrm{L}$ (Fig. 5). Nitrate, along with potassium and phosphate are among the major macronutrient required for plant growth. The usual range in treated secondary and tertiary effluents is $10-30 \mathrm{mg}$ $\mathrm{L}^{-1}$ (LENNTECH, 2014b). If the nitrate value is less than $5 \mathrm{mg} \mathrm{L}^{-1}$ there may be no restriction on the use of the water for irrigation (Duncan et al., 2000a; 2000b; Landschoot, 2015). If it is greater than $10 \mathrm{mg}$ $\mathrm{L}^{-1}$ in irrigation water, the nitrate value of the effluent may be credited towards nitrate value of the fertilizer applied to the crops. At greater than $30 \mathrm{mg} \mathrm{L}^{-1}$, there is a severe restriction to use as excess nitrogen leads to excessive vegetative growth at the expense of crop yield. Although this could be an advantage in the production of leafy vegetables, it impacts on maturity and storability of crops (Hopkins et al., 2007). It also results in more succulent plant which is more susceptible to insect and pathogens attack. 
With a nitrate concentration of $0.141 \mathrm{mg} \mathrm{L}^{-1}$ in the UNN WWTP effluent, there will be no nitrate problem and the fertilizer application rates for the crops may not need to be adjusted.

\section{Phosphate}

Phosphorus concentration in irrigation water should be as low as possible to avoid causing algal blossom in holding ponds and phosphorus loading in surface streams and lakes. The desired concentration level of phosphorus in irrigation water is less than $1.0 \mathrm{mg} \mathrm{L}^{-1}$ while the normal level is usually in the range of 0.1-0.4 $\mathrm{mg} \mathrm{L}^{-1}$ (Duncan et al., 2000a). Portmess et al. (2014) recommends a value of less than $0.1 \mathrm{mg} \mathrm{L}^{-1}$. A value of $>0.8 \mathrm{mg} \mathrm{L}^{-1}$ is considered too high (Duncan et al., $2000 \mathrm{a} ; 2000 \mathrm{~b}$ ). With a mean phosphate level of $1.845 \pm 0.14 \mathrm{mg} \mathrm{L}^{-1}$ at $95 \%$ confidence level $\mathrm{mg} / \mathrm{L}$ in the UNN WWTP effluent (Fig. 4), the effluent may not be suitable for irrigation.

\section{Potassium}

The average concentration of potassium in the tested effluent was $1.685 \pm 0.10 \mathrm{mg} \mathrm{L}^{-1}$ at $95 \%$ confidence level (Fig. 5). The normal level of potassium in irrigation water is from $<2.0$ to $20.0 \mathrm{mg} \mathrm{L}^{-1}$ (Duncan et al., 2000a; Portmess et al., 2014). A concentration level of less than $20 \mathrm{mg} \mathrm{L}^{-1}$ in irrigation water is considered desirable (Portmess et al., 2014). Therefore with a potassium level of $1.685 \mathrm{mg} \mathrm{L}^{-1}$ the UNN WWTP effluent may be considered suitable for irrigation.

\section{Bacteriological Parameters}

The mean fecal coliform count in the treated effluent was $7.42 \pm 0.49$ per $100 \mathrm{~mL}$ at $95 \%$ confidence level while the concentration of E.coli was $0.16 \pm 0.01$ per $100 \mathrm{~mL}$ at $95 \%$ confidence level. Holmes (1996) recommends a fecal coliform count of less than $1 / 100$ $\mathrm{mL}$. Havelaar et al. (2001) recommends a maximum fecal coliform level of less than $1000 / 100 \mathrm{~mL}$ for wastewater used for irrigation of crops likely to be eaten uncooked. They however suggested that irrigation must cease at least 2 weeks before harvest. A more stringent guideline of $<200$ fecal coliforms per $100 \mathrm{~mL}$ is considered more appropriate for public lawns, such as hotel lawns, with which the public may come into direct contact. With a fecal coliform count of $7.42 / 100 \mathrm{~mL}$, the treated effluent may be considered safe for irrigation purposes.

\section{Conformity with Effluent Quality Standard}

A comparison of the University of Nigeria, Nsukka (UNN) Water Treatment Plant (WWTP) effluent quality with those of Nigeria (FEPA, 1988), Malaysia, (MEQR, 2000) Mauritius (MEPA, 2002), Singapore (SEPA, 1994) and Sychelles (SEL, 2000) effluent standards is shown in Table 1. From the table the UNN WWTP effluent meets the requirement of most of those standards except for BOD, COD and TSS which are higher than the values recommended by the standards.

Table 1. Characteristics of the UNN WWTP effluent samples and its comparison with some effluent quality standards

\begin{tabular}{|c|c|c|c|c|c|c|c|c|}
\hline \multirow[b]{3}{*}{ Parameter } & \multirow[b]{3}{*}{ Units } & \multirow[b]{3}{*}{$\begin{array}{l}\text { Mean Values } \\
\text { for UNN } \\
\text { Effluent }\end{array}$} & \multicolumn{6}{|c|}{ Acceptable Effluent Quality Standard } \\
\hline & & & \multirow[b]{2}{*}{$\begin{array}{l}\text { Nigerian }^{\text {a }} \\
\text { Effluent } \\
\text { Standard }\end{array}$} & \multirow[b]{2}{*}{$\begin{array}{l}\text { Malaysian }^{\text {b }} \\
\text { Effluent } \\
\text { Standard }\end{array}$} & \multirow[b]{2}{*}{$\begin{array}{l}\text { Mauritius }^{\mathrm{c}} \\
\text { Effluent } \\
\text { Standard } \\
\end{array}$} & \multicolumn{2}{|c|}{ Singapore Effluent ${ }^{\mathrm{d}}$ Standard } & \multirow[b]{2}{*}{$\begin{array}{l}\text { Seychelles } \\
\text { Effluent } \\
\text { Standard } \\
\end{array}$} \\
\hline & & & & & & $\begin{array}{l}\text { Discharge to } \\
\text { water course }\end{array}$ & $\begin{array}{l}\text { Discharge to } \\
\text { public sewer }\end{array}$ & \\
\hline$\overline{\mathrm{EC}_{\mathrm{w}}}$ & $\mathrm{dS} / \mathrm{m}$ & 0.052 & $\mathrm{NA}^{\mathrm{f}}$ & NA & NA & NA & NA & NA \\
\hline $\mathrm{pH}$ & & 7.9 & $6-9$ & $6-9$ & $5-9$ & $6-9$ & $6-9$ & $5.5-8.5$ \\
\hline TSS & $\mathrm{mg} / \mathrm{L}$ & 119 & 30 & 50 & 35 & 50 & 400 & 30 \\
\hline TDS & $\mathrm{mg} / \mathrm{L}$ & 33.0 & 2000 & NA & NA & 2000 & 3000 & NA \\
\hline Boron & $\mathrm{mg} / \mathrm{L}$ & 0.11 & 5 & 1.0 & 0.75 & 5 & 5 & NA \\
\hline Chloride & $\mathrm{mg} / \mathrm{L}$ & 8.15 & 600 & NA & 750 & 600 & 1000 & NA \\
\hline Calcium & $\mathrm{mg} / \mathrm{L}$ & 7.85 & 200 & NA & NA & 200 & NA & NA \\
\hline Magnesium & $\mathrm{mg} / \mathrm{L}$ & 27.23 & 200 & NA & NA & 200 & NA & NA \\
\hline Sodium & $\mathrm{mg} / \mathrm{L}$ & 6.239 & NA & NA & 200 & NA & NA & NA \\
\hline Potassium & $\mathrm{mg} / \mathrm{L}$ & 1.685 & NA & NA & NA & NA & NA & NA \\
\hline Copper & $\mathrm{mg} / \mathrm{L}$ & 0.425 & $<1$ & 0.2 & 0.5 & 0.1 & 5 & 2000 \\
\hline Nitrate & $\mathrm{mg} / \mathrm{L}$ & 0.141 & 20 & NA & 10 & NA & 20 & 15 \\
\hline Phosphate & $\mathrm{mg} / \mathrm{L}$ & 1.845 & 5 & NA & 1 & NA & NA & NA \\
\hline DO & $\mathrm{mg} / \mathrm{L}$ & 5.467 & NA & NA & NA & NA & NA & $\mathrm{Na}$ \\
\hline BOD & $\mathrm{mg} / \mathrm{L}$ & 102 & 50 & 20 & 40 & 50 & 400 & 30 \\
\hline COD & $\mathrm{mg} / \mathrm{L}$ & 264 & NA & 50 & 120 & 100 & 600 & 30 \\
\hline Coliform & $\mathrm{MPN} / 100 \mathrm{~mL}$ & 7.42 & NA & NA & 400 & NA & NA & 500 \\
\hline E-Coli & MPN/ $100 \mathrm{~mL}$ & 0.16 & NA & NA & $<200$ & NA & NA & 100 \\
\hline
\end{tabular}

a. Nigerian Effluent Standard (FEPA, 1988); b. MEQR (2000); c. MEPA (2002); d. SEPA (1994); e. SEL (2000); f. NA = not available. 


\section{Conclusion and Recommendation}

From the point of view of electrical conductivity, solids, organic matter content, ion toxicity and nutrients (except phosphate), the effluent from the UNN wastewater treatment plant can be safely used for crop irrigation, especially under short term. Although the fecal coliform load is within the value allowed for irrigation water, it is recommended that irrigation must cease at least two weeks before the crop is harvested. The effluent quality also met the effluent quality standards of Nigeria and other countries except for TSS, BOD and COD values which are higher than the permissible limits.

\section{Author's Contributions}

Dr. E.A. Echiegu was the lead researcher and coordinator for the study. Miss O.R. Eya was in charge of effluent collection and storage, Engr. S.N Ugwu supervised the analyses while Dr. B.O. Ugwuishiwu prepared the original draft for the manuscript.

\section{Ethics}

The authors do not foresee any ethical issues as this manuscript has not been submitted anywhere for publication.

\section{References}

APHA and AWWA, 2012. Standard methods for the examination of water and wastewater. American Public health Association and American Water Works Association.

Ayers, R.S and D.W. Westcot, 1994. Water quality for agriculture. FAO Irrigation and Drainage Paper. FAO, Rome.

Bauder, T.A., R.M. Waskom, P.L. Sutherland and J.G. Davis, 2014. Irrigation water quality criteria. Extension factsheet No 0.506. Colorado State University.

Biswas, A.K. and A. Arar, 1988. Use of marginal quality water for plant production in Europe. Int. J. Water Res. Dev., 4: 127-141. DOI: $10.1080 / 07900628808722382$

Camberato, J., 2001. Irrigation water quality. Clemson University Turfgrass Program.

Duncan, R.R., R.N. Carrow and M. Huck, 2000a. Understanding water quality and guidelines to management. USGA Green Section Record.

Duncan, R.L., R.N. Carsow and M. Huck, 2000b. Understanding water quality and guidelines to management: An overview of challenges for water usage on golf courses for the 21 st century.
Durum, W.H., S.G. Heidel and L.J. Tison, 1960. Worldwide runoff of dissolved solids. Int. Assoc. Scientific Hydrol. Publ. 51: 618-628.

FAO, 2006. Irrigation Water Quality Guidelines. In: Water Wells and Boreholes, Misstear, B., D. Banks and L. Clark (Eds.), John Wiley and Sons, Ltd. ISBN-10: 0-470-84989-4.

FEPA, 1988. Nigerian federal environmental agency protection act 1988. Second Schedule [Regulation 3.] Effluent limitation guidelines in Nigeria for all categories of industries. Federal Environmental Protection Agency, Abuja, Nigeria.

Fipps, G., 2003. Irrigation water quality standards and salinity management strategies.

Flood, D., 1996. Irrigation water quality for BC greenhouses. Floriculture factshhet No 400-06 British Columbia Ministry of Agriculture, Fisheries and Food. Abbortford Agricultural Centre, 1767 Angus Campbell Road, Abbotford BC V3G 2M3.

Grove, A.T., 1972. The dissolved and solid load carried by some West African rivers: Senegal, Niger, Benue and Shari. J. Hydrobiol., 16: 277-300. DOI: 10.1016/0022-1694(72)90133-3

Havelaar, A., U.J. Bluemethal, M. Straws, D. Kay and J. Bartram, 2001. In: Guidelines: The Current Position. In: Water Quality Guidelines, Standards and Health, Fewtrell, L. (Ed.), World Health Organization (WHO), IWA Publishing, London.

Holmes, S., 1996. South African Water Quality Guidelines. In: Field Guide. Holmes, S. (Ed.), Department of Water Affairs and Forestry, Pretoria, Republic of South Africa ISBN-10: 0-7988-5346-8.

Hopkins, B.G., D.A. Horneck, R.G. Stevens, J.W. Ellsworth and D.M. Sullivan, 2007. Managing irrigation water quality for crop production in Pacific Northwest. Extension Publication No PNW 597-E. Oregon State University.

Hussien, G., A. Alquwaizany and A. Al-Zarah, 2010. Giidelines for irrigation water quality and water management in the Kingdom of Saudi Arabia: An Overview. J. Applied Sci., 10: 79-96. DOI: 10.3923/ijas.2010.79.96

Landschoot, P., 2015. Irrigation water quality guidelines for turf grass sites. Centre for Turfgrass Science. College of Agric Sciences. Penn State University.

LENNTECH, 2014a. SAR hazards of irrigation. Lenntech BV.

LENNTECH, 2014b. Irrigation water quality. Lenntech BV.

MEQR, 2000. Malaysian environmental quality (sewage and industrial effluent) regulation. Malaysian Sewage and Industrial Effluent Discharge Standard 2000. 
MEPA, 2002. Mauritius sewage and industrial effluent discharge standards. Mauritius Environmental Protection Act.

Oltman, R.E., 1968. Reconnaissance investigation of discharge and water quality of Amazon river. US geological Survey Circular.

Portmess, R.E., J.A. Grant, A.M. Petrovic and F.S. Rossi, 2014. Best Management Practices for New York State Golf Courses. 1st Edn., Cornell University, Ithaca, NY.

Qadir, M., B.R. Sharma, A. Bruggeman, R. Choukr and F. Karajeh, 2007. Non-conventional water resources and opportunities for water augmentation to achieve food security in water scarce countries. Agricu. Water Manage., 87: 2-22. DOI: $10.1016 /$ j.agwat.2006.03.018

SEPA, 1994. Effluent quality discharge standard. Environmental Protection (Standards) Rgulation. Seychelles Environmental Protection Act.
Shalhevet, J., 1994. Using water of marginal quality for crop production: Major issues. Agric. Water Manage., 25: 233-269.

Shuval, H.I., A. Adin, B. Fattal, E. Rawitz and P. Yekutiel, 1986. Wastewater irrigation in developing countries: Health effects and technical solutions. Technical paper No. 51. World Bank, Washington DC.

SEL, 2000. Code of practice on pollution control. Appendix 9: The Singapore Allowable limits for trade effluent discharged into public sewer/water courses/controlled water courses. Singapore Environmental Law.

Vogel, A.I., 2000. Vogel's-Textbook of Quantitative Chemical Analysis. 6th Edn., /Revised by Mendham, J., R.C. Denney, J.D. Barnes, M. Thomas. Harlow, England; New York: Prentice Hall, xxvii + 806 pp ISBN 0582226287; 9780582226289 . 